\title{
Monoclonal antibody to macrophages (EMB/11) labels macrophages and microglial cells in human brain
}

\author{
MARGARET M ESIRI,* J O'D McGEE $\dagger$ \\ From the University of Oxford, *Department of Neuropathology, Radcliffe Infirmary, and the University of \\ Oxford, $\uparrow$ Nuffield Department of Pathology, John Radcliffe Hospital, Oxford
}

SUMMARY Normal and diseased human central nervous system (CNS) tissues were studied immunohistochemically by a monoclonal antibody to human macrophages (EBM/11), antisera to glial fibrillary acidic protein (anti-GFAP), and $\alpha$-1-antichymotrypsin ( $\alpha 1-A C T)$. EBM/11 reacted with brain macrophages located mainly around blood vessels in normal brain; it also reacted with resting microglia in normal brain and with numerous reactive microglia and macrophages in brain tumours and inflammatory lesions. Microglia did not react with anti-GFAP or $\alpha 1-A C T$. An EBM/11 positive phenotype, therefore, is shared by microglia and macrophages and suggests that microglial cells form a specialised part of the mononuclear phagocyte system.

The nature and origin of microglial cells in the central nervous system (CNS) has been a subject of debate for many decades. del Rio Hortega ${ }^{12}$ was the first to identify cells termed "resting" microglia in normal undamaged CNS and "reactive" or "activated" microglia in traumatic and inflammatory CNS lesions. Intermediate forms also existed, and del Rio Hortega considered that the two forms were interchangeable and were of mesodermal origin. This view has been supported by light and ultrastructural histochemistry. ${ }^{3}$ Experimental autoradiographic studies have indicated that at least some of the cells with morphological features of activated microglia and macrophages infiltrating CNS lesions are derived from circulating blood mononuclear cells. ${ }^{45}$ Perivascular adventitial cells also provide a source of phagocytic cells in injured brain parenchyma. ${ }^{6}$ Some authors have recently questioned the view that resting and activated microglia are derived from blood monocytes; this has arisen because antigens normally expressed by macrophages and blood monocytes are not detectable in resting microglia. ${ }^{45-10}$ Macrophages, however, are a heterogeneous population, both functionally and in their antigenic properties. The fact that certain macrophage markers have not been detected on resting microglia does not, therefore, conclusively refute their originating from blood monocytes. Furthermore, recent studies on the localisation of the mouse macrophage marker F4/80 in

Accepted for publication 23 January 1986 developing and adult mouse brain and retina, which show that $F 4 / 80$ positive cells migrate into the mouse CNS during development and subsequently differentiate into cells with appearances of resting microglia, ${ }^{11} 12$ suggest that these cells may have a macrophage function. The monoclonal antibody $\mathrm{EBM} / 11$, raised against lung macrophages, has been shown to react with a cytoplasmic determinant in human macrophages from various organs ${ }^{13}$ and other cells of presumptive macrophage origin (E Bliss, unpublished observations). ${ }^{14}$ 15 In a preliminary survey of undiseased necropsy material EBM/11 reacted with microglial cells in human brain (E Bliss, unpublished observations). ${ }^{1316}$

This report shows that EBM/11 reacts not only with macrophages but also with microglia in normal and diseased human CNS tissues, indicating that microglial cells and macrophages are phenotypically (and presumably) functionally similar.

\section{Material and methods}

Fresh frozen cryostat sections were prepared from surgical and necropsy specimens from the following: normal cerebral cortex and white matter (five cases), brain stem (three cases), and spinal cord (three cases); cerebral gliomas (six cases), meningiomas (two cases), pituitary adenoma (one case), multiple sclerosis plaques and surrounding white matter (five cases), progressive multifocal leucoencephalopathy (one case), acute perivenous leucoencephalitis (one case), 
cerebral infarction (three cases), cerebral granuloma (two cases), acute necrotising encephalitis (one case), and head injury (two cases).

Sections $10 \mu \mathrm{m}$ thick were mounted on glass slides, fixed in acetone for 10 minutes, washed in $0.15 \mathrm{M} / 1$ sodium chloride buffered with Tris-hydrochloric acid, pH 7.4 (Tris saline), and covered by the EBM/11 antibody, applied as neat ascitic fluid for 30 minutes at $22^{\circ} \mathrm{C}$. After washing with Tris saline peroxidase conjugated rabbit antimouse IgG (Dako) (diluted 1/50 with $1 / 20$ normal human serum) was applied to the slides for $\mathbf{3 0}$ minutes, washed in Tris saline incubated with diaminobenzidine and $\mathrm{H}_{2} \mathrm{O}_{2}$ for five minutes. Slides were counterstained with haematoxylin. Sections adjacent to those treated with EBM/11 antibody were incubated with antibody to glial fibrillary acidic protein anti-GFAP (Monosan). In selected cases double staining was done with EBM/11 antibody, using peroxidase labelled second antibody for detection of this antibody and alkaline phosphatase labelled second antibody for detection of anti-GFAP. Immunoreactivity of CNS tissues with EBM/11 antibody was also compared with reactivity to $\alpha 1$-antichymotrypsin antiserum ( $\alpha 1$-ACT) (Dako) (1/1000 dilution), which was detected by using the PAP immunoperoxidase technique on adjacent sections.

\section{Results}

NORMAL CENTRAL NERVOUS SYSTEM

A regular array of small, bipolar, or multipolar cells reactive for EBM/11 was shown in cerebral white matter (Fig. 1). These cells, therefore, had the typical $\underline{0}$ appearances of microglial cells. Nuclei of reactive cells were spaced roughly $30-70 \mu \mathrm{m}$ apart, and their $\stackrel{\vec{\rho}}{\stackrel{F}{9}}$ processes in places lay within smaller distances of $\overrightarrow{0}$ each other but did not appear to overlap. Similar rel- 흠 atively regular spacing of $\mathrm{EBM} / 11$ reactive microglial के cells was seen in the white matter of the spinal cord $\Phi$ and brain stem and in grey matter of the cerebral cortex. Some of these cells lay close to capillaries and others, in grey matter, close to neurone cell bodies. $\mathrm{EBM} / 11$ reacted with a cytoplasmic component of the $\overrightarrow{\vec{\omega}}$ positively stained cells, and the reaction product was $\stackrel{\omega}{\sigma}$ distinctly granular in appearance. The nuclei of reac- $\frac{\vec{g}}{0}$ tive cells both in grey and white matter were small, moderately stained with haematoxylin, oval, or comma shaped, and had stippled chromatin. These $\dot{\sigma}$ small EBM/11-reactive cells in CNS parenchymal $\vec{G}$ tissues did not react with either the antiserum to $ᄋ$ $\alpha 1-\mathrm{ACT}$ or that to GFAP (Figs. 1 and 2). The latter antiserum labels astrocytes, which are larger and have $c$ longer smoother processes than microglia (Fig. 2).

In addition to reacting with the microglial cells $\overrightarrow{0}$ described above, EBM/11 reacted with larger cells of $\infty_{\infty}$ polygonal or spindle shape, with abundant cytoplasm found immediately adjacent to parenchymal blood vessels of various types (Fig. 1). Similar cells were detected in the leptomeninges where they were also often, but not exclusively, associated with blood vessels (Fig. 3). The distribution and appearance of these $\stackrel{\mathbb{Q}}{\unrhd}$ cells suggested that they were macrophages and peri- $\overrightarrow{\vec{O}}$

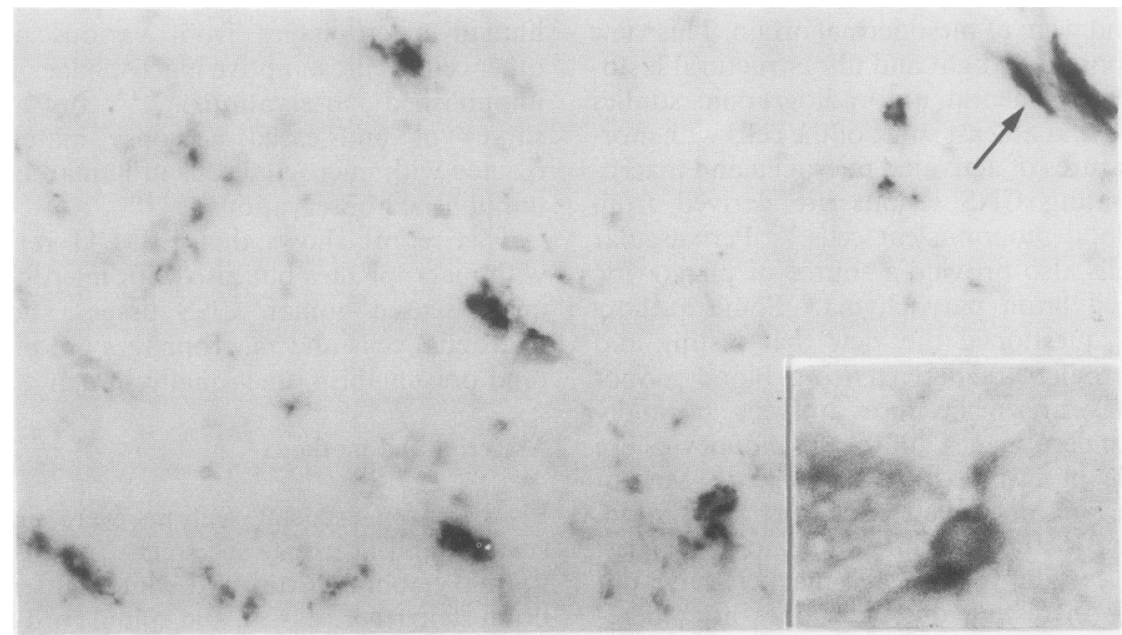

Fig. 1 Cryostat section of cerebral white matter treated with monoclonal antibody EBM/11 followed by peroxidase reaction with diaminobenzidine showing reaction product in scattered microglial cells. Top right shows small venule (arrow) flanked by two reactive perivascular cells, which are larger than parenchymal microglial cells. (Counterstained with haematoxylin.) $\times$ 350. Inset: bottom right, single bipolar microglial cell at higher power. $\times 700$. 


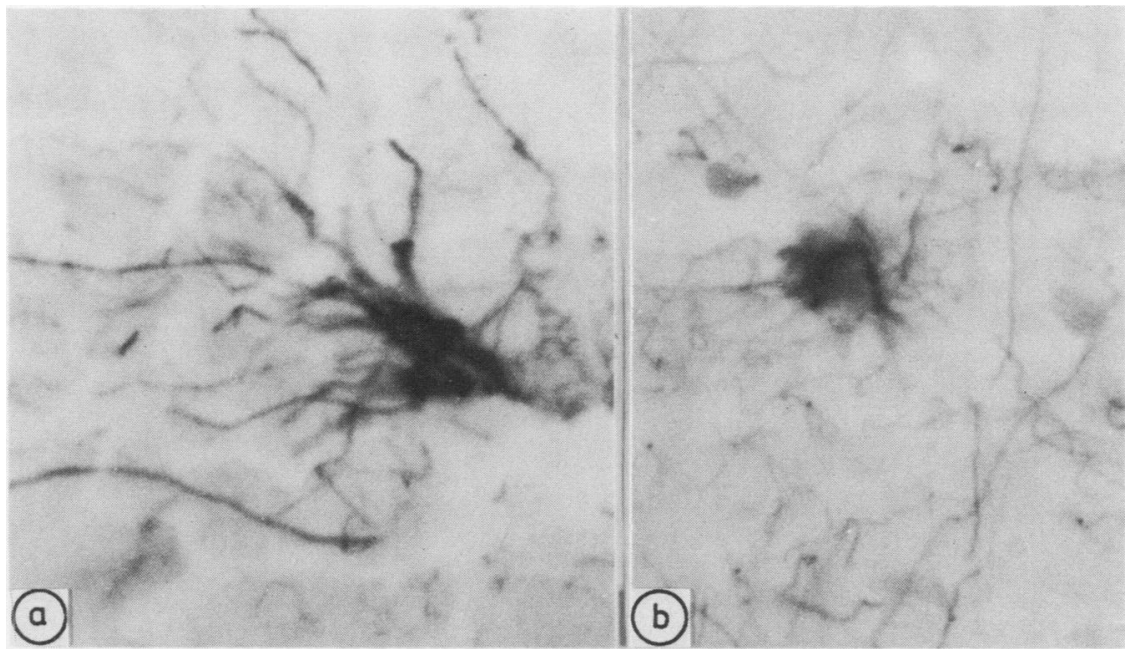

Fig. 2 Examples of white matter astrocytes from same block as Fig. 1 shown with anti-GFAP antibody and peroxidase reaction with diaminobenzidine. These cells are larger and have more numerous and longer processes than cells shown by monoclonal antibody EBM/11 seen in Fig. 1 . $\times 950$.

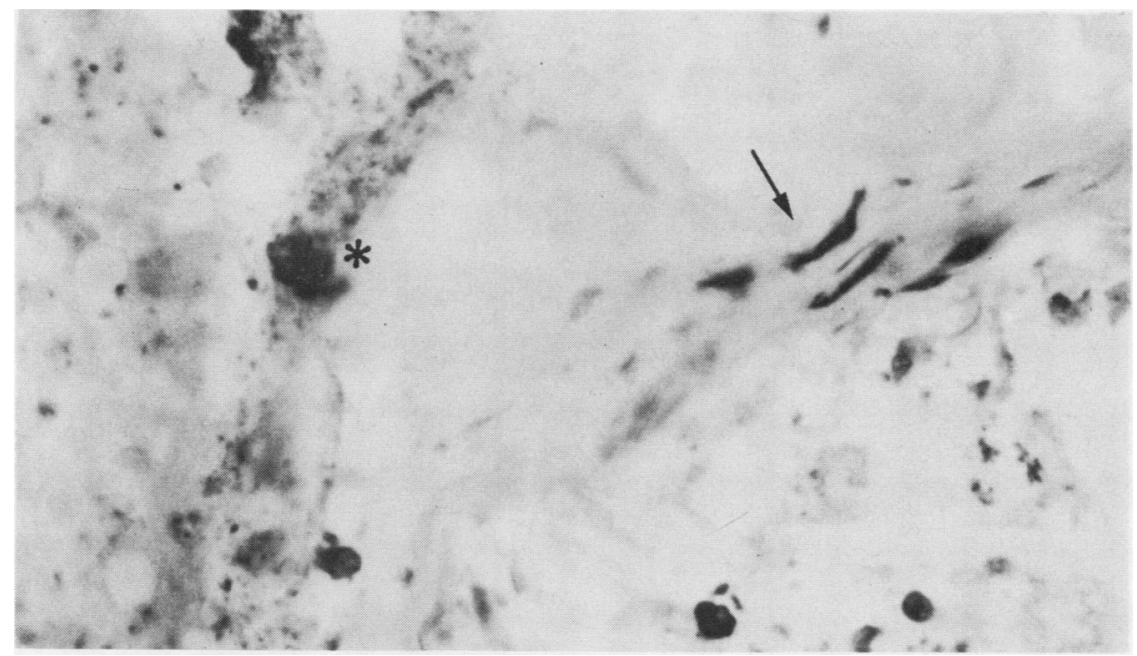

Fig. 3 Cryostat section of spinal cord leptomeninges containing plump macrophages (example asterisked) and perivascular spindle shaped cells (arrow) reacting with monoclonal antibody EBM/11. (Peroxidase reaction with diaminobenzidine counterstained with haematoxylin.) $\times 450$.

cytes. Some, but not all of the cells of this type, reacted weakly with the antiserum to $\alpha$-ACT.

\section{TUMOURS}

Cerebral gliomas contained scattered EBM/11 positive cells that were larger than those seen in normal brain and had a more rounded outline with fewer processes (Fig. 4). Their density varied from one part of a tumour to another and from tumour to tumour.
There was an accumulation of EBM/11 positive cells at the edge of necrotic areas in glioblastomas (Fig. 5). The pattern of reaction with EBM/11 was quite different from that with the GFAP antiserum, which reacted with many of the tumour cells in astrocytomas and glioblastomas (Fig. 6). In general, the $\mathrm{EBM} / 11$ reactive cells were ubiquitous and quite numerous in gliomas. In one glial tumour from a child with tuberous sclerosis almost half the cells within the 


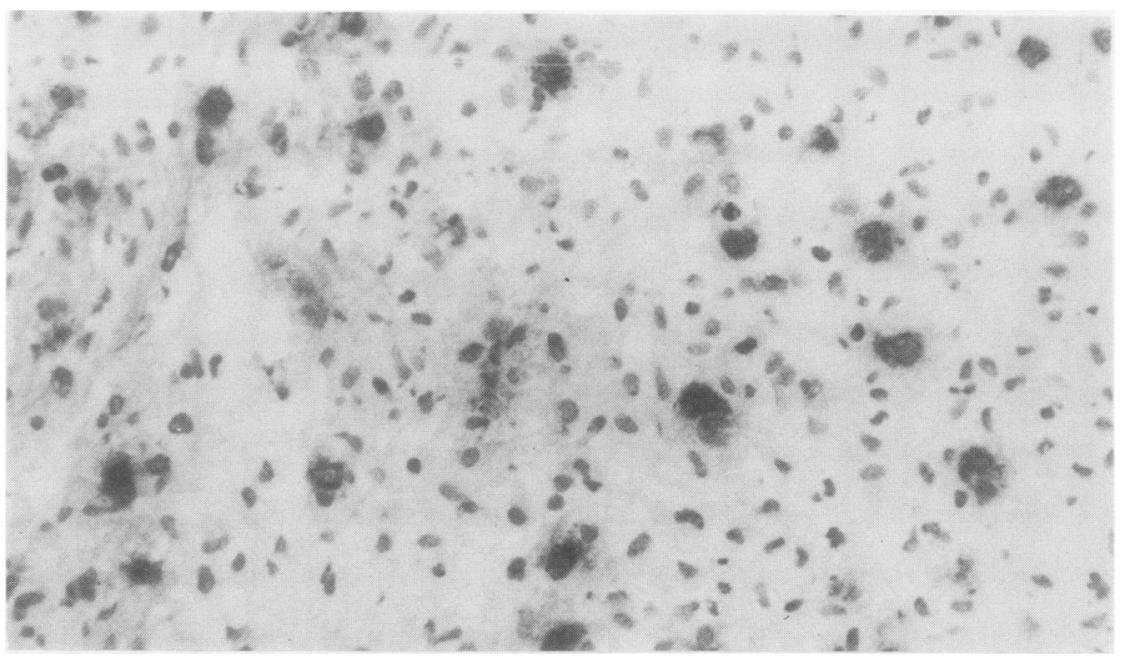

Fig. 4 Cryostat section of infiltrating cerebral astrocytoma treated with monoclonal antibody $E B M / 11$ followed by peroxidase reaction with diaminobenzidine. Positively reacting plump cells are scattered throughout tumour. Nuclei of unreactive astrocytes are interspersed between $E B M / 11$ reactive cells. (Counterstained with haematoxylin.) $\times 300$.

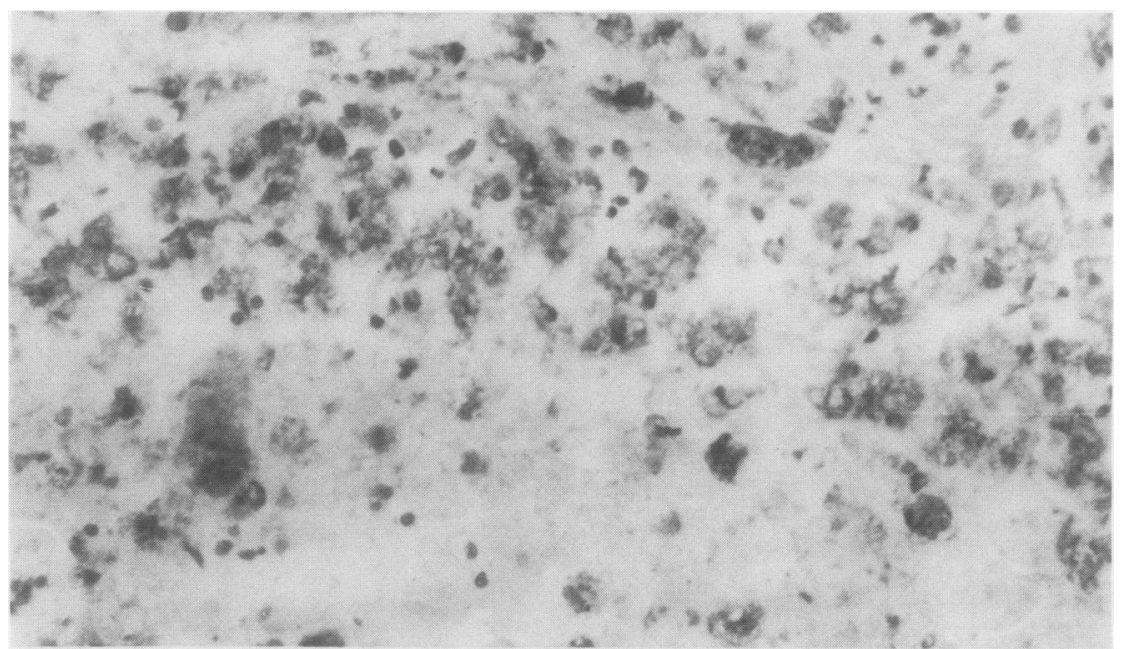

Fig. 5 Cryostat sections of cerebral glioblastoma treated with monoclonal antibody EBM/11 followed by peroxidase reaction with diaminobenzidine. Zone containing reactive macrophages runs fom left to right, bordering an area of necrosis below. (Counterstained with haematoxylin.) $\times 250$.

tumour section reacted strongly with EBM/11, but notably, these cells were smaller and had smaller less pleomorphic nuclei than those of the unreactive cells (Fig. 7).

The meningiomas studied showed some foci of positive reactivity with $\mathrm{EBM} / 11$. In these tumours the reactive cells were spindle shaped and appeared to be part of the tumour itself.

The pituitary adenoma tumour cells showed no reactivity with $\mathrm{EBM} / 11$, but there were occasional? positively reacting large cells adjacent to blood vessels $\stackrel{\varrho}{\stackrel{C}{\complement}}$ in this tumour.

The gliomas and other tumours studied were not? convincingly reactive with the $\alpha 1$-ACT antibody.

INFLAMMATORY AND OTHER NON-NEOPLASTIC LESIONS

Large macrophages or Gitter cells from the case of $\underset{x}{ }$

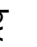




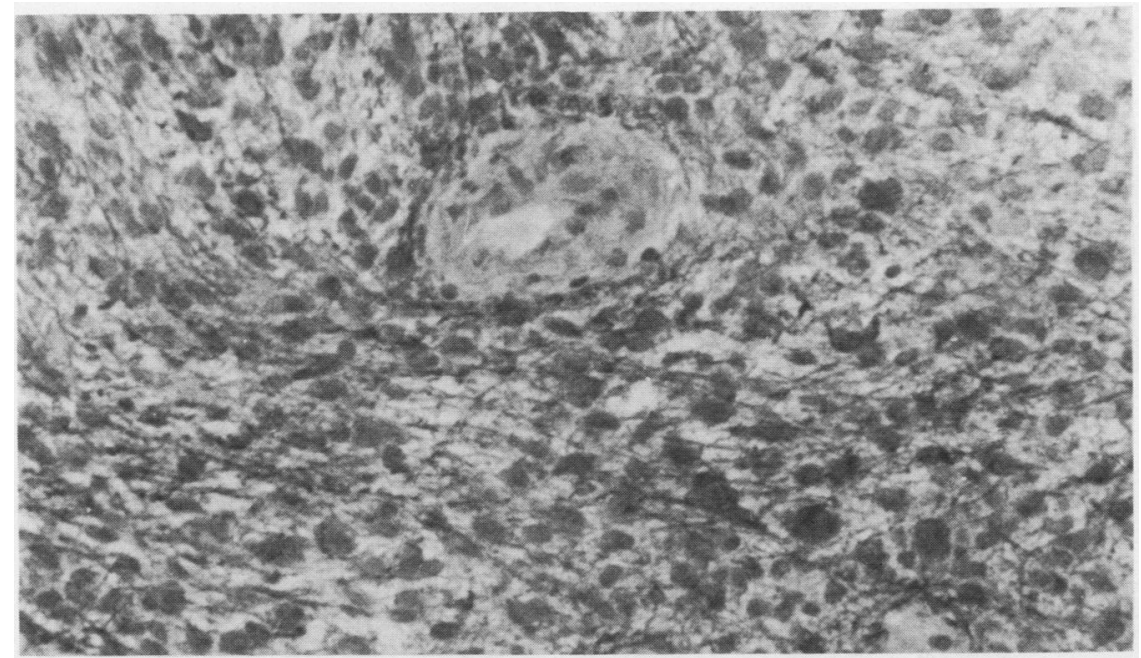

Fig. 6 Cryostat section of astrocytoma illustrated in Fig. 4 treated with anti-GFAP antiserum followed by peroxidase reaction with diaminobenzidine. Numerous astrocyte cell bodies and their processes are stained. Compare appearances with those of Fig. 4. (Counterstained with haematoxylin.) $\times 300$.

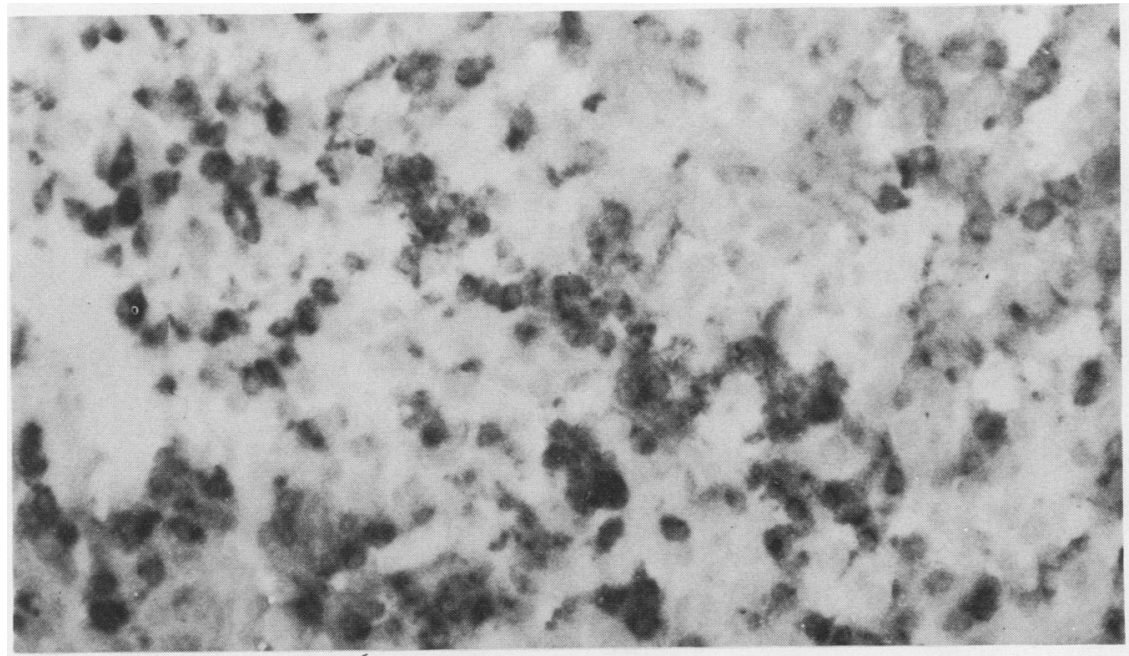

Fig. 7 Cryostat section of large celled astrocytoma from subependymal region from a case of tuberous sclerosis treated with monoclonal antibody EBM/11 following by the diaminobenzidine reaction. Numerous $E B M / 11$ positive cells are present interspersed among the unreactive tumour cells. (Counterstained with haematoxylin.) $\times 300$.

necrotising encephalitis, the cases of cerebral infarction, and the margins of multiple sclerosis plaques reacted strongly with EBM/11 (Fig. 8). The cerebral granulomas also contained numerous intensely reactive spindle and epithelioid type cells. Clusters of reactive microglial cells in the cases of head injury were also easily identified and reacted intensely with EBM/11 (Fig. 9). Some of the Gitter cells reacted weakly with $\alpha 1-\mathrm{ACT}$ antiserum; the
EBM/11 antibody showed far more reactive cells that stained more intensely. In lesions of progressive multifocal leucoencephalopathy and acute perivenous encephalitis numerous large EBM/11 reactive cells were present, whereas few cells reacted for $\alpha 1$-ACT. All of these lesions also contained numerous large reactive astrocytes. For the most part, astrocytes were clearly unreactive with EBM/11, but the astrocytes in the progressive multifocal leucoencephalopathy 


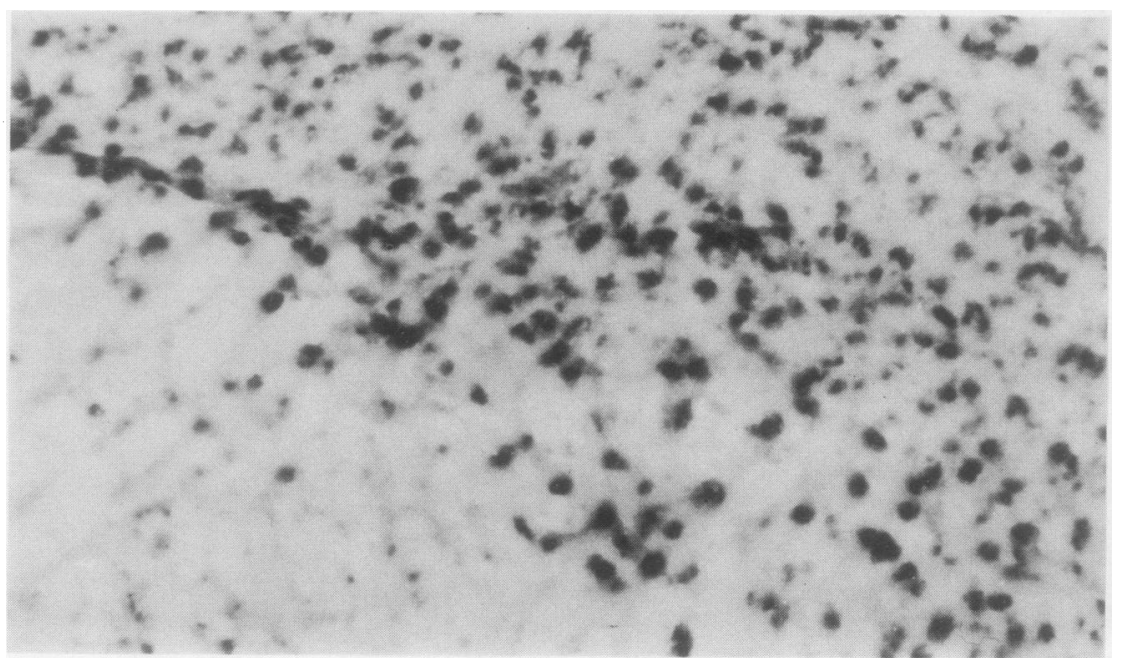

Fig. 8 Cryostat section from margin of multiple sclerosis plaque (bottom left) treated with monoclonal antibody $E B M / 11$ followed by diaminobenzidine reaction. Large numbers of $E B M / 11$ reactive cells occupy marginal zone. (Counterstained with haematoxylin.) $\times 120$.

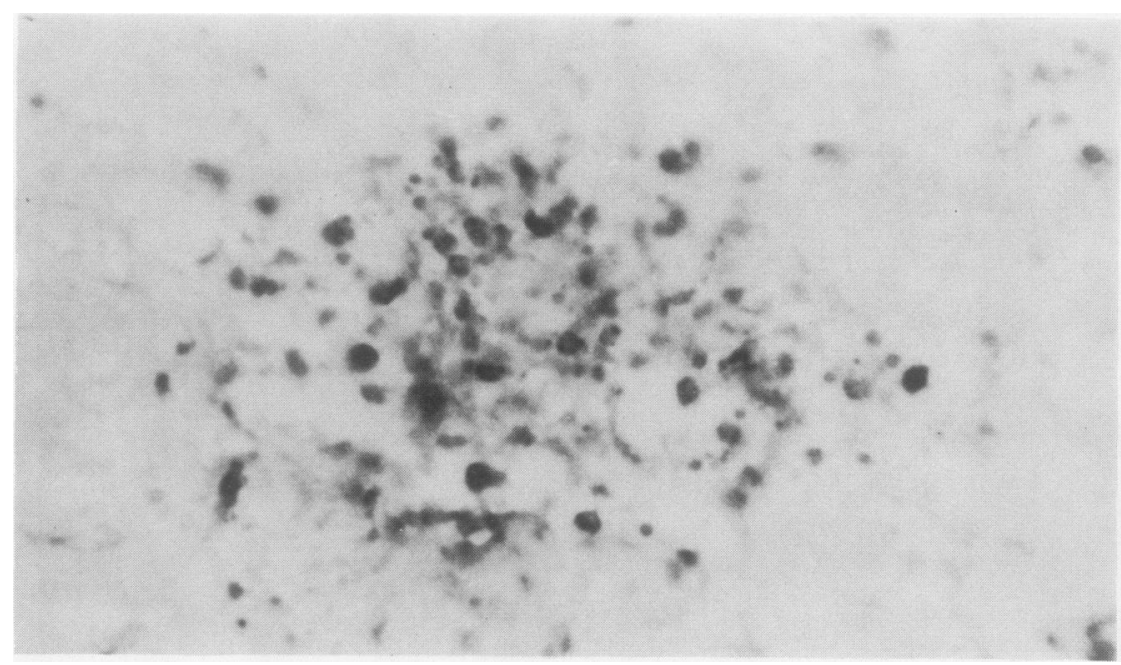

Fig. 9 Cryostat section from cerebrum from a case of severe head injury with eight days' survival treated with monoclonal antibody EBM/11 followed by the diaminobenzidine reaction. Cluster of reactive microglial cells is strongly reactive. (Counterstained with haematoxylin.) $\times 350$.

lesions and at the margins of some multiple sclerosis plaques showed a weak diffuse reaction with $\mathrm{EBM} / 11$, though this was much less intense and lacked the granular quality of the staining seen in macrophages and microglial cells.

\section{Discussion}

We found the EBM/11 antibody to be an excellent reagent for detecting microglial cells in undiseased human brain. The arrays of small cells with multiple processes shown in this study closely resembled those identified as reactive with the macrophage specific antibody $F 4 / 80$ in mouse brain. (E Bliss, unpublished observations). These cells correspond morphologically to the classically described microglial cells of del Rio Hortega. ${ }^{12}$ In addition to these parenchymal microglial cells, EBM/11 also reacted with macro- 
phage like perivascular and leptomeningeal cells in normal brain.

In cerebral glial tumours we detected a high number of large reactive microglial cells and macrophages. Heavy macrophage infiltration of human gliomas was also found by Morantz et al. ${ }^{17}$ EBM/11 positive cells tended to form an array in tumours lacking necrosis, rather like that of microglial cells in normal brain. These cells may represent a modified population of microglial cells in tissue that has been diffusely infiltrated rather than destroyed by the tumour. In tumours with extensive necrosis large numbers of additional macrophages were also present, particularly around the necrotic zones. In non-neoplastic cerebral disease strongly positive $\mathrm{EBM} / 11$ cells were present in large numbers. Results of comparison of these cells with those positive for GFAP generally showed no overlap, but in some cases in which numerous EBM/11 positive cells were present GFAP positive astrocytes also showed a weak diffuse reaction for $E B M / 11$. This may result from release of the EBM/11 antigen from macrophages and uptake into reactive astrocytes. In general, $E B M / 11$ is a sensitive and specific marker for macrophages and microglial cells in the CNS. It reacts with many more cells than does antiserum to $\alpha 1-\mathrm{ACT}$ and it shows the normal microglial population more reliably than silver stains. It does, however, require the use of frozen as opposed to formalin fixed material. It is likely to prove a valuable tool in differentiating macrophages and microglial cells from other CNS components and for studying entry of macrophages into the human CNS during development. Our findings using EBM/11 support del Rio Hortega's original view that microglia form a part, albeit a specialised part, of the mononuclear phagocyte system.

"Microglioma" and "microgliomatosis" are now presumed to be lymphoreticular malignancies. Fresh tissues from these conditions were not available when this study was done. The reaction of $\mathrm{EBM} / 11$ in these disorders and cerebral lymphomas will form part of a future study to determine whether any or all of these malignancies express this macrophage marker.

This work was supported by grants from the Multiple Sclerosis Society of Great Britain and Northern Ireland (MME) and the Cancer Research Campaign (JO'DMcG). Miss M Reading gave excellent technical help. Miss L Watts typed the manuscript.

\section{References}

${ }^{1}$ del Rio Hortega P. El tercer elemento de los centros nerviosos. I. La microglia. II. Intervención de la microglia en los procesos patologicas. III. Naturaleza probable de la microglia. Boletin de la Sociedad Española de Biologia 1919;9:69-120.

${ }^{2}$ del Rio Hortega P. Microglia. In: Penfield's cytology and cellular pathology of the nervous system. Vol. 2, New York: Harper and Row, 1932:483-534.

${ }^{3}$ Murabe Y, Sano Y. Morphological studies on neuroglia. VI. Postnatal development of microglial cells. Cell Tissue Res 1982;225:469-85.

${ }^{4}$ Oemichen M. Mononuclear phagocytes in the central nervous system. Berlin: Springer Verlag, 1978:41-65.

${ }^{5}$ Oemichen M. Functional properties of microglia. In: Smith WT, Cavanage JB, eds. Recent advances in neuropathology. Vol. 2. Edinburgh: Churchill Livingstone, 1982:83-107.

${ }^{6}$ Brierley JB, Brown AW. The origin of lipid phagocytes in the central nervous system. II. The adventitia of blood vessels. J Comp Neurol 1982;211:407-17.

${ }^{7}$ Tsuchihashi Y, Kitamura, T, Fujita S. Immunofluorescence studies of monocytes in the injured rat brain. Acta Neuropathol 1981;53:213-9.

${ }^{8}$ Fujita S, Tsuchihashi Y, Kitamura T. Absence of hematogenous cells in the normal brain tissue as revealed by leukocyte-specific immunofluorescent staining. $J$ Neuropathol Exp Neurol 1978;37:615.

${ }^{9}$ Persson LI, Ronnback L. Demonstration of cross reaction between antimacrophage antibodies and mononuclear mesodermal cells. Experientia 1979;35:381-2.

${ }^{10}$ Wood GW, Gollahon KA, Tilzer SA, Vats T, Morantz RA. The failure of microglia in normal brain to exhibit mononuclear phagocyte markers. J Neuropathol Exp Neurol 1979;38:369-76.

${ }^{11}$ Hume DA, Perry VH, Gordon S. Immunohistochemical localisation of macrophage-specific antigen in developing mouse retina: phagocytosis of dying neurons and differentiation of microglial cells to form a regular array in the plexiform layers. $J$ Cell Biol 1983;97:253-7.

${ }^{12}$ Perry VH, Hume DA, Gordon S. Immunohistochemical localisation of macrophages and microglia in the adult and developing mouse brain. Neuroscience 1985;15:313-26.

${ }^{13}$ Franklin WA, Pulford K, Brunangelo F, et al. Immunohistological analysis of human mononuclear phagocytes and dendritic cells using monoclonal antibodies. Lab Invest 1986;54:322-36.

${ }^{14}$ Theaker JM, Gatter KC, Heryet A, Evans DJ, McGee J O'D. Giant cell myocarditis: evidence of the macrophage origin of the giant cells. J Clin Pathol 1985;38:160-4.

${ }^{15}$ Athanasou NA, Bliss E, Gatter KC, Heryet A, Woods CG, McGee J O'D. An immunohistological study of giant cell tumour of bone: evidence for an osteoclast origin of the giant cells. J Pathol 1985;147:153-9.

${ }^{16}$ Bliss E, Naien M, Burns J, Bell K, McGee J O'D. Quantitation of macrophages in human breast cancer using monoclonal antibody (EBM/11) to human macrophages. J Pathol 1984;143:A6.

${ }^{17}$ Morantz RA, Wood GW, Foster M, Clark M, Gollahon K. Macrophages in experimental and human brain tumours. Part 2: studies of the macrophage content of human brain tumours. $J$ Neurosurg 1979;50:305-11.

Requests for reprints to: Professor J O'D McGee, Nuffield Department of Pathology, John Radcliffe Hospital, Oxford OX3 9DU, England. 
Glycosylated Hemoglobins: Methods of Analysis and Clinical Applications. Clinical and Biochemical Analysis Series. Vol 19. EC Abraham. (Pp 256; \$71-50.) Marcell Dekker Inc. 1985.

This expensive but informative book covers the structure and functional features of the various glycosylated haemoglobins, methods for their analysis, and interpretation of results. The final chapter is devoted to a review of non-enzymatic glycosylation of other proteins in the body including albumin, lipoproteins, insulin, collagen and erythrocyte membrane, and peripheral nerve proteins.

This is the first major book on the subject and is a valuable reference for those clinical chemists, haematologists, and any one interested in diabetes.

BRENDA SLAVIN

\section{Notices}

\section{Supraregional Assay Service \\ Protein Reference Units Handbook of Clinical Immunochemistry}

This handbook is intended as a guide to the services available from the SAS Protein Reference Units. Since the establishment of the Supraregional Assay Service in 1974 the range of assays available at, and the number of requests made of, the SAS Protein Reference Units has increased considerably. Certain assays have been devolved to regional or district laboratories and new assays have been added to the repertoire. In addition to describing the assays available from the Units under the SAS, the handbook also describes the clinical indications for assays devolved from the SAS and the assays currently under development, which may be added to the repertoire in the future. Later sections describe the external quality assessment services that are available to laboratories doing immunochemistry and calibrants available from public source.

Copies ( $£ 6.00$ inclusive of postage) are available from: The Director, Protein Reference Unit, Royal Hallamshire Hospital, Sheffield S10 2JF.

\section{ASSOCIATION OF CLINICAL PATHOLOGISTS}

\section{JUNIOR MEMBERSHIP}

Junior membership of the Association is available to all trainees in pathology for up to six years after the start of training. The annual subscription is $£ 15$ and may be claimed against tax. All junior members receive copies of the Journal of Clinical Pathology. Other benefits include membership of the Junior Members' Group and a regular junior members' newsletter; the ACP Newsletter and all other documents regularly sent to full members including the postgraduate education programme.

Junior membership normally leads to full membership of the Association, which represents medical pathologists in hospital practice.

Junior membership is not available to trainees overseas and those on short term training schemes in this country. Requests on an individual basis will be considered.

Apply to: Dr PP Anthony, Education Secretary, Postgraduate Medical School, Barrack Road, Exeter EX2 5DW, Devon.

\section{Afternoon of gastrointestinal pathology in honour of Dr Basil C Morson,}

VRD, MA, DM, FRCP, FRCS, FRCPath

Dr Basil Morson will retire from his post as Consultant Pathologist to St Mark's Hospital in November 1986.

In his honour a symposium on gastrointestinal pathology has been organised through the pathology departments of St Mark's and St Bartholomew's Hospitals.

Speakers are:

Dr DW Day;
Dr JR Jass;
Professor JE Lennard-Jones;
Dr DA Levison;
Dr AB Price;
Dr IC Talbot;
Dr GT Williams;
Professor NA Wright

The symposium will be held at: The Robin Brook Centre, St Bartholomew's Hospital, London EC1, on Wednesday 12 November 1986, at $2 \mathrm{pm}$.

Admission free.
Fourth International Symposium on
Morphometry in Morphological
diagnosis

Royal Society of Medicine, September 10-12, 1986

Although covering image analysis using large systems, many of the contributions will describe the use of small micro based systems suitable for use in a district general hospital. One session will be devoted to flow cytometry. The emphasis throughout will be on clinical applications and clinical usefulness. The programme includes invited expert guest speakers: Bahr (USA); Watson (UK); Ploem (Netherlands); Wied (USA); Aver (Sweden); Baak (Netherlands); Stenkqvist (Sweden); and Collan (Finland).

There will also be a wide range of proferred papers and poster demonstrations, particularly on the applications of morphometry to gut, bone, breast, lymphoreticular and urogenital pathology. A pleasing feature of the proferred papers are the contributions correlating structure and function, which is an ideal aim for clinical pathologists.

A limited number of places now remain for attendance at the symposium. These will be allocated on a strictly first come, first served basis.

Further details may be obtained from: Miss Elaine Gill, Gill Medical, 429 Tamworth Road, Long Eaton, Nottingham NG10 3JT, England.

\section{Correction}

The title of a paper by J O'D McGee et al (39:615-21.) published as Monoclonal antibody to macrophages (EMB/11) labels macrophages and microglial cells in human brain should have been: Monoclonal antibody to macrophages (EBM/11) labels macrophages and microglial cells in human brain. 